\title{
Stress Regulation, Physical Activity, and Perseverance in Spanish Teenagers with Perfectionist Trends
}

\author{
Juan González Hernández ${ }^{1}$, Antonio Jesús Muñoz-Villena ${ }^{2}$ and Manuel Gómez-López ${ }^{3, *}$ (i) \\ 1 Department of Personality, Evaluation and Psychological Treatment, University of Granada, \\ 18071 Granada, Spain; jgonzalez@ugr.es \\ 2 Department of Educación Física, Deporte y Motricidad Humana, Autonomous University of Madrid, \\ 28049 Madrid, Spain; aj.munnoz@gmail.com \\ 3 Department of Physical Activity and Sport, Faculty of Sports Science, University of Murcia, \\ C/Argentina, s/n., Santiago de la Ribera, 30720 Murcia, Spain \\ * Correspondence: mgomezlop@um.es; Tel.: +34-868-888-674; Fax: +34-868-888-672
}

Received: 15 April 2018; Accepted: 7 May 2018; Published: 9 May 2018

\begin{abstract}
Stress as an emotional response with adaptive function can obstruct both academic performance and psychosocial and physiological functioning when it is recurrent, persistent, and intense. Individual characteristics and regular physical activity produce differences in ways of coping with pressure situations, stressing the necessity of teenagers handling them in an effective way for their psychological adjustment and well-being. The purpose of this investigation was to identify how the frequency of physical activity and the influence of certain personality traits (perfectionism and perseverance) moderate stress. The sample was composed of 127 teenage students; tests were administered to measure perfectionism, perseverance, perceived stress, including an ad hoc sociodemographic questionnaire. The results show that particular conditions/skills have a moderating effect on stress perception in students with perfectionist maladaptive tendencies. Training in perseverance allows students to develop resources for handling stress, making it possible to achieve personal standards as well as adapt to one's context.
\end{abstract}

Keywords: personality; beliefs; perseverance; emotions; physical activity

\section{Introduction}

In the last few decades, interest in researching personality traits and their relationship with the psychological response produced in the educational environment, has led to the discovery of different influential factors besides intelligence. Opening up this line of research has shown that, apart from intellectual factors, academic performance is influenced by adaptive emotional variables [1], behavioral variables [2], social variables [3], and cognitive variables [4]. In addition, the link between personality factors and other factors associated with the school environment like physical activity (PA) practice is relevant [5], due to the fact that it influences individual identity setting (intrapersonal) combined with the social response to other similar people (interpersonal).

Chamorro-Premuzic and Furnham [6] describe a student who possesses personality traits that are considered to characterize an efficient person and can also be applied to several psychosocial contexts (hard-working, family-oriented, competitive, etc.). For that matter, perfectionism and perseverance relate to how students attempt to reach their goals, and to know what to do when they face difficulties in achieving their goals.

Perfectionism as a feature of the personality (conscientiousness) is considered a multidimensional construct: we identified two common components in the different definitions: high personal standards and concerns about evaluation. The first component refers to the search for perfection and the 
establishment of high expectations or personal standards. The second component includes fear of failure, negative assessment, and discrepancies between expectations and performance.

The main models that try to explain perfectionism describe resources and subjective perceptions about the necessity of a good performance (personal demands, organization, fear of failure, doubts about actions, parental expectations, and parental criticism) [7], or suggest factors that derive from a perfectionist condition (self-oriented perfectionism, other-oriented perfectionism, socially prescribed perfectionism, and perfectionist self-presentation). However, both are focused on a permanent and interactive process between the person and the context in which their life takes place.

Both models use different taxonomies to name the dimensions that are part of the construct. Two different forms of perfectionism are identified [8]. The maladaptive form is related to dysfunctional constructs (depression beliefs, anxiety synthomatology, procrastination goals, stress negative perception, etc.) and links fear indicators to making mistakes, socially prescribed perfectionism, or discrepancies between expectations and results. On the contrary, the adaptive form associated with functional constructs (positive affect, high self-esteem beliefs, life satisfaction, self-efficacy, assessment to coping the challenge) links personal standard indicators and self-oriented perfectionism [9].

Consequently, it has been pointed out that perfectionism does not interfere in intrapersonal aspects [10] because it focuses on the individual process derived from the social response according to gender conditions and socioeconomic status.

Frequency of regular PA has been linked with health and academic performance, and the benefits can be highlighted at both physical and cognitive levels [11]. There is evidence that the practice of PA has organic benefits and is a protective factor against diseases such as diabetes, cardiovascular disorders, and obesity, contributing to psychomotor development in adolescence. In addition, it has been linked to the balance of negative emotional states [12], lower levels of anxiety [13], better cognitive, and expression features of character and personality [14]. Perceptions of psychological well-being and attitudes about PA, are described as indicators of normalized development of the adolescent's personality and psychosocial development.

While at an intrapersonal level in the educational environment, maladaptive perfectionism has been shown to have a negative impact on academic performance, being related to procrastination [15] or the relinquishing of goals [16], other studies have highlighted the importance of perfectionist profiles on a greater number of prosocial behaviors [17].

Studies in a sportive practice context have associated different perfectionism dimensions and the cognitive and behavioral aspects that motivate the PA practice [1,18]. What these studies found was that adaptive perfectionism is associated, in a positive way, with several aspects such as self-efficacy, planning, and persistence in PA, while maladaptive perfectionism is related to doubts about exercise and avoidance of PA [19].

The literature describes perseverance as persistence and tenacity in achieving one's goals, and points out the efforts of young students to adapt and their influence on both stress responses [20] and well-being responses [21]. This dimension is said to be connected to tendencies to experience job satisfaction, allowing a higher probability of academic success [22], sporting performance [23-25], and professional success [26] as a result of the involvement and commitment of each individual, as well as greater positivity with regards to performance [27] or to attitudes towards learning and PA practice [28].

In addition, Dweck and Leggert [20] propose that there are two student behavioral patterns that prevail in the achievement of goals. On the one hand, pupils with orientation to learning goals can be characterized by continuous improvement; on the other, students oriented towards performance goals might try to avoid all evaluation, showing that they are unable to persist against obstacles, and have higher anxiety and stress [29]. Regular PA is more highly correlated with the first case than the second [14].

Stress is a perceived consequence of the context in which an individual grows up, particularly if it is perceived as threatening. First, the individual perceives the stressful situation, then he/she 
evaluates the strategies or styles that the situation demands; the interaction produces an emotional response functional or disfuntional according with the psychological needs or demands perceived, respectively [30]. From this bidimensional model it is understood that stimuli or environments are not stressful in themselves; what matters is whether the individual perceives them as stressful or not.

Stress as a process of adaptation to academic demands generates different emotional responses (fear, happiness, sadness, surprise) and cognition (concerns) that develop jointly [31]. Therefore, it is a generator of an emotional response with important adaptive, social, and motivational functions; meanwhile, the recurrence, persistence, and intensity of these responses can hamper an individual's psychosocial and physiological functioning. The degree of stress and intensity and quality of an emotional response are determined by the interaction among ambient, personality, and expectation conditions.

Insufficient emotional intelligence to face and regulate the emotions arising from a stress situation has been linked to psychopathological disorders [32], substance abuse and compulsive gambling [33], burnout syndrome [34], and poor academic performance [35]. The evidence found so far indicates that emotional regulation mediates dysfunction in teenagers with impulsive behavior.

Considering psychosocial status conditions, several researchers agree about associating stress with gender differences [36], age [37], or academic level [38].

Therefore, based on the theoretical models previously described, the objectives of the current research are to analyze relationships between personality indicators (perfectionism and perseverance) and stress perception according to gender and educational level, with the hypothesis that the relationship between perfectionism and stress perception will be influenced by the moderating force caused by different patterns of perseverance and the frequency of PA practice.

\section{Materials and Methods}

\subsection{Subjects and Design}

The current research was done with a quantitative methodology and a causal cross-sectional design. An incidental sample of 127 teenagers who study in a private center in Granada, Spain, aged 13 to 16 years old $(\mathrm{M}=14.56$; $\mathrm{DT}=1.57)$, was available. ESO (Secondary Obligatory Education) and middle-level training program students were distributed depending on their age: 13 years $(36.2 \%)$, 14 years $(21.3 \%), 15$ years $(13.4 \%), 16$ years $(13.4 \%)$, and 17 years $(15.7 \%)$; and depending on their academic level: first year of secondary school $(29.1 \%)$, second year of secondary school $(14.2 \%)$, third year of secondary school $(21.3 \%)$, fourth year of secondary school $(16.5 \%)$, and middle-level training program $(18.9 \%)$. The authors grouped the first and second years of secondary school into the first cycle of ESO and the third and fourth years of secondary education into the second cycle of secondary obligatory education. A $64.6 \%$ were male and $35.4 \%$ were female, withal of upper-middle socioeconomic class and with a PA average of 3.18 days a week $(\mathrm{DT}=0.64)$.

\subsection{Measures}

Self-administered questionnaires consisting of three items were created by the researchers. The questionnaire contained information linked with the subject (age, gender, practice of physical activity, and academic level) and consisted of a closed-response format.

\subsubsection{Physical Activity (PA)}

To quantify the variables referring to physical activity and sports versus sedentary behavior, items on the questionnaire address the variables of physical activity and sedentary behavior within the Health Behavior study in School-aged Children (HBCS) [39]. Composed of five items of high scientific consensus about the frequency of PA practice, it includes three items assessed on a Likert scale from 0 ("no day") to 7 ("every day of the week") and two dichotomous (YES)/NO) questions as to whether daily activity lasts for $60 \mathrm{~min}$ or $30 \mathrm{~min}$. 


\subsubsection{Perfectionism}

The version of the Frost Multidimensional Perfectionism Scale (FMPS) that we used was adapted for the Spanish population by Carrasco, Belloch, and Perpiña [40]. The scale consists of 35 items that measure the following four subscales: expectations of success (nine items), organization (six items), fear of failure (11 items), and parental influence (nine items). Likert scales have been used for each of the answer options $(1=$ total disagreement, $5=$ total agreement). The reliability coefficient for this sample was $\alpha=0.87$. It is also possible to calculate a "global perfectionism index" using the sum of the absolute values of the items adaptive perfectionism (expectations of success and organization) and maladaptive perfectionism (fear of failure and parental influence).

\subsubsection{Perseverance}

The perseverance subscale (Big Five Questionnaire ([BFQ]) was applied to items belonging to the perseverance category of the Big Five Questionnaire, adapted for the Spanish population by Bermudez [41]. Of the 12 items available, six are written in a positive way and the rest in a negative way. The students answer via a Likert scale, which varies from (1) "absolutely false" to (5) "absolutely true." For the current research, the instrument shows an acceptable score $(\alpha=0.71)$ after Cronbach's alpha estimation.

\subsubsection{Perceived Stress}

A version of the Perceived Stress Scale (PSS) adapted for the Spanish population [42] has been used. This instrument consists of 14 items: seven written in a positive way and seven written in a negative way. The total scores were obtained by summing all the answers after inverting the corresponding items, to obtain scores that range from 0 to 56 ; the highest marks are indicative of a higher level of perceived stress. The participants score their level according to each item using a Likert scale and five alternatives (from $0=$ never to $4=$ very often). The Cronbach's alpha coefficient in this work was $\alpha=0.81$.

\subsection{Procedure}

For the administration of this research, permission was requested from the management team of a private education center located in the province of Alicante, Spain. The proposal was disseminated through the guidance department to the tutors and teachers of each group, explaining to them the purpose of the research, the method used to obtain the data, and the necessity of obtaining informed consent from the parents of the teenagers who were to be part of the research. The sample was chosen due to its specific characteristics and the agreement between the educational center and the researchers.

Ethical standards were maintained throughout the research according to the Helsinki Declaration. Parents of the teenagers were informed of the voluntary participation, confidentiality, and anonymity of data. All the questionnaires were administered during school time. The explanation of the instructions by the researchers and the responses took approximately $30 \mathrm{~min}$.

\subsection{Statistical Analysis}

We used the statistical package SPSS for Windows, version 23.0, for the codification and analysis of data. In the current research the following analyses were codified and realized with the statistical package SPSS for Windows, version 23.0: descriptive statistics (means and standard deviations), internal reliability (Alpha's Cronbach coefficient), normal distribution (Kolmogorov-Smirnov), tests for difference of means (Student's $t$-test and ANOVA), Pearson's correlations, and moderation test.

\section{Results}

Table 1 shows descriptive data (mean and standard deviation) of the variables studied and the normality test. The Kolmogorov-Smirnov (K-S) statistical test determined that organization, 
personal standards, fear of failure, parental expectations, perceived stress, and perseverance were adjusted to the assumption of normality. Regarding measures of key trends and the measures of dispersion, it may be seen that when comparing samples related to the educational cycle variable, the first cycle suggests greater levels of parental expectations (F2.125 $=3.75 ; p=0.02)$ and PA practice for the second cycle (F2.125 $=2.12 ; p=0.03)$. There seems to have been a trend in males in favor of perseverance $(\mathrm{t} 2.125=.82 ; p=0.41)$ and in females in favor of perceived stress $(\mathrm{t} 2.125=-1.20 ; p=0.22)$, although these were not significant.

The correlation between the variables (Table 2) highlights the starting causal relationship of the variables. It is possible to observe that perseverance retains an inverse relationship with stress perception, while stress perception has a direct relationship with fear, parental expectations, and age. PA practice shows a positive correlation with organization and personal standards, and both dimensions reveal the best resources for adaptive perfectionism. In the same way, as PA increases, stress perception also increases, with a highly significant relationship.

Finally, a moderation analysis has been done (Figure 1), revealing the moderating effect of perseverance on stress perception, in interaction with maladaptive perfectionism when levels PA are moderates. The main effect of maladaptive perfectionism in the perception of the stress $(\beta=-0.44$; $p=0.02)$ is when PA is moderate. Also, when students show low maladaptive perfectionism, perseverance turns into a resource that allows them to lower their perception of stress in an effective way. Significant moderated relations do not appear when PA is low or high.

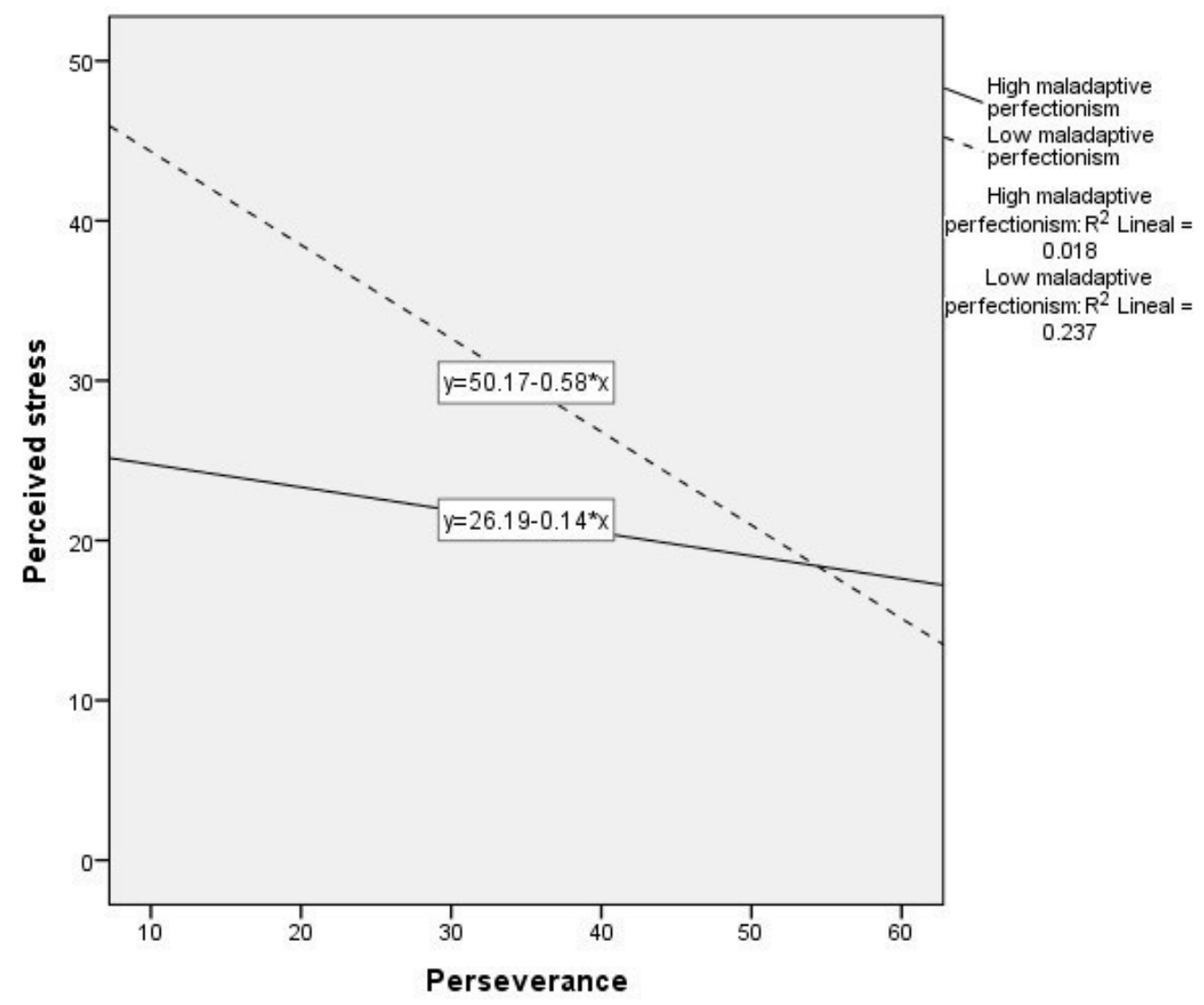

Figure 1. Predictable relationship of maladaptive perfectionism over the stress perception moderating perseverance, with middle levels of physical activity. 
Table 1. Descriptive ratio statistics, normality test, gender differences (Student's $t$-test), and educational cycle (ANOVA).

\begin{tabular}{|c|c|c|c|c|c|c|c|c|c|c|c|}
\hline & \multirow{3}{*}{$K-S$} & \multirow{3}{*}{$M(D T)(n=127)$} & \multicolumn{4}{|c|}{ Gender } & \multicolumn{5}{|c|}{ Academic Year } \\
\hline & & & \multicolumn{2}{|c|}{$M(D T)$} & \multirow[b]{2}{*}{$t_{(125)}$} & \multirow[b]{2}{*}{ Sig } & \multicolumn{3}{|c|}{$M(D T)$} & \multirow[b]{2}{*}{$F_{(125)}$} & \multirow[b]{2}{*}{ Sig } \\
\hline & & & $\mathrm{M}(n=82)$ & $\mathrm{F}(n=45)$ & & & $\begin{array}{c}1^{\circ} \text { Cycle } \\
(n=55)\end{array}$ & $\begin{array}{c}2^{\circ} \text { Cycle } \\
(n=48)\end{array}$ & $\begin{array}{c}3^{\circ} \text { Cycle } \\
(n=24)\end{array}$ & & \\
\hline Organization & 0.20 & $21.66(5.43)$ & $21.43(5.52)$ & $22.07(5.30)$ & -0.63 & 0.52 & $21.86(5.76)$ & $21.72(5.36)$ & $21.05(4.94)$ & 0.19 & 0.82 \\
\hline Personal standards & 0.20 & $24.70(7.07)$ & $24.88(7.16)$ & $24.38(6.97)$ & 0.38 & 0.70 & $25.09(7.48)$ & $23.13(6.50)$ & $26.96(6.72)$ & 2.55 & 0.08 \\
\hline Fear of failure & 0.20 & $24.90(7.59)$ & $24.95(7.63)$ & $24.80(7.61)$ & 0.10 & 0.91 & $24.91(8.40)$ & $24.17(6.59)$ & $26.30(7.65)$ & 0.62 & 0.53 \\
\hline Parental expectations & 0.20 & $20.52(6.61)$ & $20.59(6.82)$ & $20.40(6.30)$ & 0.15 & 0.88 & $21.93(6.62)$ & $18.52(6.42)$ & $21.29(6.21)$ & 3.75 & $0.02 *$ \\
\hline Perceived stress & 0.18 & $24.15(8.04)$ & $23.15(8.65)$ & $25.31(6.71)$ & -1.20 & 0.22 & $23.95(7.28)$ & $23.13(8.34)$ & $26.67(8.84)$ & 1.59 & 0.20 \\
\hline Perseverance & 0.20 & $42.54(6.69)$ & $42.90(7.31)$ & $41.89(5.40)$ & 0.81 & 0.41 & 41.67 (7.43) & $44.08(5.66)$ & $41.46(6.48)$ & 2.08 & 0.12 \\
\hline Physical activity & 0.19 & $3.18(0.64)$ & $3.65(1.02)$ & $2.83(1.36)$ & 1.27 & $0.04 *$ & $3.04(0.74)$ & $3.76(1.03)$ & $2.83(1.25)$ & 2.12 & $0.03 *$ \\
\hline
\end{tabular}

Table 2. Correlation between psychological response, age, and physical activity in teenage students.

\begin{tabular}{|c|c|c|c|c|c|c|c|c|}
\hline & 1 & 2 & 3 & 4 & 5 & 6 & 7 & 8 \\
\hline 1. Organization & - & & & & & & & \\
\hline 2. Personal standards & $0.19 *$ & - & & & & & & \\
\hline 3. Fear of failure & -0.00 & $0.46^{* *}$ & - & & & & & \\
\hline 4. Parental expectations & -0.01 & $-0.50 * *$ & $0.59 * *$ & - & & & & \\
\hline 5. Perseverance & 0.08 & 0.09 & -0.13 & -0.15 & - & & & \\
\hline 6. Perceived stress & -0.13 & 0.11 & $0.42 * *$ & $0.28^{* *}$ & $-0.038^{* *}$ & - & & \\
\hline 7. Age & -0.12 & 0.03 & 0.02 & -0.04 & -0.03 & $0.21 *$ & - & \\
\hline 8. Physical activity & $0.48^{*}$ & $0.42 *$ & 0.46 & 0.23 & $0.57^{* *}$ & $0.61 * *$ & $-0.53 *$ & - \\
\hline
\end{tabular}

* Significant at $p<0.05 ; * *$ significant at $p<0.01$. 


\section{Discussion}

The current study aims to show the relationships between perfectionism and stress perception in teenagers, and to suggest how they can be mediated by different perseverance patterns and the frequency of PA. We have tried to identify the influence of gender and academic year in terms of the perception of stress and subdimensions of personality (perseverance and perfectionism indicators) and daily or weekly frequency of PA.

The sample chosen for this research was adolescent students for several reasons. Firstly, the scientific literature has pointed out that perfectionism as a relevant predictor of poor adjustment and stress begins during adolescence [43]. Adolescence is considered one of the periods of greatest vulnerability for the individual since it is necessary to face a variety of internal and external demands but teenagers often do not possess sufficient emotional resources to handle stress. The specific challenges and obligations of this period are in line with the biological and physical changes of puberty, together with variations in cognitive, social, and emotional functioning.

Secondly, as Gaeta and Martin [44] show, secondary education students face a more demanding and broader study program; in addition to this, it is necessary to consider the biological, emotional, and social changes inherent to their development. Education is currently designed in a competitive way such that students face heavy social, family, and academic demands. Given the interaction between constantly changing factors, it is hard to avoid stressful situations (exams, projects, new learning situations, etc.) during adolescence.

Adolescents show differences in their response to stress in terms of gender and academic level. In addition, our results have shown variations in terms of PA depending on the school year: students seem to decrease their physical activity as they get older ( $1^{\circ} \mathrm{ESO}, 3^{\circ} \mathrm{ESO}$ y $\left.1^{\circ} \mathrm{BTO}\right)$. Similar results are obtained in studies with high samples of adolescents $[45,46]$.

Despite results obtained in relation to the first objective have not shown significant gender differences, average marks on stress perception have been higher in female subjects than in male. Like previous studies [31], no differences have been found in stress perception according to gender. Following the line of study focused on perfectionism in students [10], it is affirmed that there are no gender differences in terms of perfectionism indicators.

The results of the correlation analysis show that the relationship between PA practice and adaptive perfectionism indicators is positive. Similarly, the relationship between stress perception with PA is positively significant, explaining why high levels of PA can increase the risks of stress perception too. This result contrasts with other studies $[47,48]$ that show a negative correlation between PA practice and stress perception in adolescents.

The same cannot be said about differences found into parental expectations, according educational cycle, since no previous studies have been found to support these trends. At the beginning of the academic year students are influenced in their objectives and goals by parental expectations, but as time goes individuals can generate goals in a more realistic way and owing to that, feel motivated to persevere despite the obstacles or barriers encountered.

Until some decades ago perfectionism was understood as dysfunctional, being related to eating disorders [43,45], anxiety and depression [32], and stress [31,33]. Previous studies starting from this perspective have tried to explain perfectionism without understanding potential factors that can serve as emotional resources to withstand stress [49].

The results of this research are innovative and have shown the moderating effect of perseverance on stress perception. This discovery is in line with the claims of other authors [50,51]; according to them, having the resources to emotionally regulate stress allows a student to have the necessary perseverance to achieve his/her goals.

It is useful to understand and explain what individual or personal variables (resources) act as moderators on the health consequences of stress, enabling students to face adversity in an effective way and maintain good psychological adjustment. Linked to this, demographic and occupational factors are revealed as possible variables related directly or indirectly to the level and handling of stress. 
The results obtained help explain the adaptive resources of students, showing that certain personality trends are associated with effective handling of stress, and therefore with psychological well-being and positive emotions; however, this research has some limitations. In future studies it would be useful to have a sample of teenagers belonging to other types of schools (estate schools, charter schools, etc.) as well as different educational levels (basic education, high school, non-regulated teaching, etc.).

In adolescence, due to the high variety of personal and social challenges that young people face, it is necessary not only to develop cognitive skills but also emotional and motivational skills that could be applied to personal, social, and academic performance. Emotional response is a significant predictor of social and personal performance, playing a role in the adaptive capacity to handle pressure situations, achieve emotional self-control, and meet objectives, as the evidence has shown so far. Training teenagers with dysfunctional perfectionism patterns through tasks that require perseverance consists of both regulating the stress process and providing tools for its management like regular PA, allowing for the construction of an efficient and functional personality.

Author Contributions: J.G.H. conceived of the hypothesis of this study. J.G.H., A.J.M.-V. and M.G.-L. participated in data collection. J.G.H. analyzed the data. All authors contributed to the interpretation of data and statistical analysis and wrote the paper. All authors read and approved the final manuscript.

Funding: This research received no external funding.

Conflicts of Interest: The authors declare no conflict of interest.

\section{References}

1. Flett, G.L.; Hewitt, P.L. A proposed framework for preventing perfectionism and promoting resilience and mental health among vulnerable children and adolescents. Psychol. Sch. 2014, 51, 899-912. [CrossRef]

2. Steel, P.; Klingsieck, K.B. Academic procrastination: Psychological antecedents revisited. Aust. Psychol. 2016, 51, 36-46. [CrossRef]

3. Fullchange, A.; Furlong, M.J. An exploration of effects of bullying victimization from a complete mental health perspective. Sage Open 2016, 6, 1-12. [CrossRef]

4. Stoeber, J.; Roche, D.L. Affect intensity contributes to perfectionistic self-presentation in adolescents beyond perfectionism. J. Ration.-Emot. Cogn.-Behav. Ther. 2014, 32, 164-180. [CrossRef]

5. Light, R.L. Children, Young People and Sport: Studies on Experience and Meaning; Cambridge Scholars Publishing: Newcastle upon Tyne, UK, 2016.

6. Chamorro-Premuzic, T.; Furnham, A. Personality and Intelectual Competence; Psychology Press: London, UK, 2014.

7. Frost, R.O.; Marten, P.; Lahart, C.; Rosenblate, R. The dimensions of perfectionism. Cogn. Ther. Res. 1990, 14, 449-468. [CrossRef]

8. Gaudreau, P.; Thompson, A. Testing a $2 \times 2$ model of dispositional perfectionism. Person. Individ. Differ. 2010, 48, 532-537. [CrossRef]

9. Stoeber, J. The dual nature of perfectionism in sports: Relationships with emotion, motivation, and performance. Int. Rev. Sport Exerc. Psychol. 2011, 4, 128-145. [CrossRef]

10. Hassan, H.K.; Abd-El-Fattah, S.B.; Abd-El-Maugoud, M.K.; Badary, A.H.A. Perfectionism and performance expectations at university: Does gender still matter? Eur. J. Educ. Psychol. 2012, 5, 133-147. [CrossRef]

11. Carbonel, A.; Aparicio, V.; Ruiz, J.; Ortega, F.; Delgado, M. Guía de Recomendaciones para la Actividad Física. Junta de Andalucía. Consejería de Salud. 2010. Available online: http://www.juntadeandalucia. es/salud/servicios/contenidos/andaluciaessalud/docs/130/Guia_Recomendaciones_AF.pdf (accessed on 14 March 2018).

12. Poudevigne, M.S.; O'Connor, P. A review of physical activity patterns in pregnant women and their relationship to psychological health. Sports Med. 2006, 36, 19-38. [CrossRef] [PubMed]

13. Olmedilla, A.; Enrique Ortega, E.; Candel, N. Ansiedad, depresión y práctica de ejercicio físico en estudiantes universitarias. Apunts. Medicina de l'Esport 2010, 45, 175-180. [CrossRef]

14. González, J.; Portolés, A. Actividad física extraescolar: Relaciones con la motivación educativa, rendimiento académico y conductas asociadas a la salud. Revista Iberoamericana de Psicología del Ejercicio y el Deporte 2014, 9, 51-65. 
15. Burnam, A.; Komarraju, M.; Hamel, R.; Nadler, D.R. Do adaptive perfectionism and self-determined motivation reduce academic procrastination? Learn. Individ. Differ. 2014, 36, 165-172. [CrossRef]

16. Salanova, M.; Martínez, I.; Bresó, E.; Llorens, S.; Grau, R. Bienestar psicológico en estudiantes universitarios: Facilitadores y obstaculizadores del desempeño académico. Anales de Psicología 2005, 21, 170-180.

17. Plenty, S.; Östberg, V.; Modin, B. The Role of Psychosocial School Conditions in Adolescent Prosocial Behaviour. Sch. Psychol. Int. 2015, 36, 283-300. [CrossRef]

18. Hill, A.P.; Hall, H.K.; Appleton, P.R.; Kozub, S.R. Perfectionism and burnout in junior elite soccer players: The mediating influence of unconditional self-acceptance. Psychol. Sport Exerc. 2008, 9, 630-644. [CrossRef]

19. Longbottom, J.-L.; Grove, B.; Dimmock, J. An examination of perfectionism traits and physical activity motivation. Psychol. Sport Exerc. 2010, 11, 574-581. [CrossRef]

20. Dweck, C.S.; Leggett, E.L. A social-cognitive approach to motivation and personality. Psychol. Rev. 1988, 95, 256-273. [CrossRef]

21. Besançon, M.; Fenouillet, F.; Shankland, R. Influence of school environment on adolescents' creative potential, motivation and well-being. Learn. Individ. Differ. 2015, 43, 178-184. [CrossRef]

22. Niño de Guzmán, I.; Calderón, A.; Cassaretto, M. Personalidad y rendimiento académico en estudiantes universitarios. Rev. Psicol. PUCP 2003, 21, 121-143.

23. Moles, T.A.; Auerbach, A.D.; Petrie, T.A. Grit happens: Moderating effects on motivational feedback and sport performance. J. Appl. Sport Psychol. 2017, 29, 418-433. [CrossRef]

24. Moreau, N.; Chanteau, O.; Benoît, M.; Dumas, M.P.; Laurin-lamothe, A.; Parlavecchio, L.; Lester, C. Sports activities in a psychosocial perspective: Preliminary analysis of adolescent participation in sports challenges. Int. Rev. Sociol. Sport 2014, 49, 85-101. [CrossRef]

25. Lauer, E.E.; Zakrajsek, R.A.; Lauer, L. The role of sport psychology for young athletes. In Sport Psychology for Young Athletes; Routledge: London, UK, 2017; pp. 9-20.

26. Lloyd, L.; Calnan, M.; Cameron, A.; Seymour, J.; Smith, R. Identity in the four the age: Perseverance, adaptation and maintaining dignity. Ageing Soc. 2014, 34, 1-19. [CrossRef]

27. McCormick, M.P.; Cappella, E.; O'Connor, E.E.; McClowry, S.G. Context matters for social-emotional learning: Examining variation in program impact by dimensions of school climate. Am. J. Commun. Psychol. 2015, 56, 101-119. [CrossRef] [PubMed]

28. Carriedo, A. Metas de logro, diversión y persistencia-esfuerzo en estudiantes de Educación Física durante una unidad didáctica sobre judo. Magister 2015, 27, 51-58. [CrossRef]

29. Turnnidge, J.; Côté, J.; Hancock, D.J. Positive youth development from sport to life: Explicit or implicit transfer? Quest 2014, 66, 203-217. [CrossRef]

30. Lazarus, R.S.; Folkman, S. Estrés y Procesos Cognitivos; Martínez Roca: Barcelona, Spain, 1986.

31. Giota, J.; Gustafsson, J.-E. Perceived demands of schooling, stress and mental health: Changes from grade 6 to grade 9 as a function of gender and cognitive ability. Stress Health 2017, 33, 253-266. [CrossRef] [PubMed]

32. McLaughlin, K.A.; Hatzenbuehler, M.L.; Mennin, D.S.; Nolen-Hoeksema, S. Emotion dysregulation and adolescent psychopathology: A prospective study. Behav. Res. Ther. 2011, 49, 544-554. [CrossRef] [PubMed]

33. Schreiber, L.N.; Grant, J.E.; Odlaug, B.L. Emotion regulation and impulsivity in young adults. J. Psychiatr. Res. 2012, 46, 651-658. [CrossRef] [PubMed]

34. Casanova, J.; Benedicto, S.; Luna, F.; Maldonado, C. Burnout, inteligencia emocional y rendimiento académico: Un estudio en alumnado de medicina. Revista de Investigación y Docencia Creativa 2016, 5, 1-6.

35. Hood, W.; Bradley, G.L.; Ferguson, S. Mediated effects of perceived discrimination on adolescent academic achievement: A test of four models. J. Adolesc. 2017, 54, 82-93. [CrossRef] [PubMed]

36. García-Ros, R.; Pérez-González, F.; Pérez-Blasco, J.; Natividad, L.A. Evaluación del estrés académico en estudiantes de nueva incorporación a la universidad. Rev. Latinoam. Psicol. 2012, 44, 143-154.

37. Burger, K.; Samuel, R. The Role of Perceived Stress and Self-Efficacy in Young People's Life Satisfaction: A Longitudinal Study. J. Youth Adolesc. 2017, 46, 78-90. [CrossRef] [PubMed]

38. Shankar, N.L.; Park, C.L. Effects of stress on students' physical and mental health and academic success. Int. J. Sch. Educ. Psychol. 2016, 4, 5-9. [CrossRef]

39. WHO. World Recomendations about Physical Activity for Health; OMS: Geneva, Switzerland, 2010.

40. Carrasco, A.; Belloch, A.; Perpiñá, C. La evaluación del perfeccionismo: Utilidad de la Escala Multidimensional de Perfeccionismo en población española. Análisis y Modificación de Conducta 2010, 36, 49-65. 
41. Bermúdez, J. Cuestionario "Big Five". Adaptación al Castellano del Cuestionario BFQ de G.V. Caprara, Barbaranelli y Borgogni; Tea Ediciones: Madrid, Spain, 1995.

42. Remor, E.; Carrobles, J.A. Versión Española de la escala de estrés percibido (PSS-14): Estudio psicométrico en una muestra VIH+. Ansiedad y Estrés 2001, 7, 195-201.

43. Nilsson, K.; Sundbom, E.; Hagglof, B. A longitudinal study of perfectionism in adolescent onset anorexia nervosa-restricting type. Eur. Eat. Disord. Rev. 2008, 16, 386-394. [CrossRef] [PubMed]

44. Gaeta, M.L.; Martín, P. Estrés y adolescencia: Estrategias de afrontamiento y autorregulación en el contexto escolar. Stvdivm Revista de Humanidades 2009, 15, 327-344.

45. Dugas, L.R.; Ebersole, K.; Schoeller, D.; Yanovski, J.A.; Barquera, S.; Rivera, J.; Durazo-Arzivu, R.; Luke, A. Very low levels of energy expenditure among preadolescent Mexican-American girls. Int. J. Pediatr. Obes. 2008, 3, 123-126. [CrossRef] [PubMed]

46. Martín, M.; Barripedro, M.I.; Martínez del Castillo, J.; Jiménez-Beatty, J.; Rivero-Herráiz, A. Diferencias de género en los hábitos de actividad física en población adulta en la Comunidad de Madrid. Revista Internacional de Ciencias del Deporte 2014, 10, 319-335. [CrossRef]

47. Cariney, J.; Kwan, M.Y.; Veldhuizen, S.; Faulkner, G.E. Who uses exercise as a coping strategy for stress? Results from a national survey of Canadians. J. Phys. Act. Health 2013, 11, 908-916. [CrossRef] [PubMed]

48. González, J.; Garcés de los Fayos, E.J.; García del Castillo, A. Percepción de bienestar psicológico y fomento de la práctica de actividad física en población adolescente. Revista Internacional de Ciencias Sociales y Humanidades 2011, 21, 55-71.

49. Wu, D.; Wang, K.; Wei, D.; Chen, Q.; Du, X.; Yang, J.; Qiu, J. Perfectionism mediated the relationship between brain structure variation and negative emotion in a nonclinical sample. Cogn. Affect. Behav. Neurosci. 2017, 17, 211-223. [CrossRef] [PubMed]

50. Hall, N.C.; Sampasivam, L.; Muis, K.R.; Ranellucci, J. Achievement goals and emotions: The mediational roles of perceived progress, control, and value. Br. J. Educ. Psychol. 2016, 86, 313-330. [CrossRef] [PubMed]

51. Pekrun, R. Using Self-Report to Assess Emotions in Education. In Methodological Advances in Research on Emotion and Education; Springer International Publishing: New York, NY, USA, 2016; pp. 43-54.

(C) 2018 by the authors. Licensee MDPI, Basel, Switzerland. This article is an open access article distributed under the terms and conditions of the Creative Commons Attribution (CC BY) license (http://creativecommons.org/licenses/by/4.0/). 